\title{
Habitat requirements of black mudfish (Neochanna diversus) in the Waikato region, North Island, New Zealand
}

\section{B. J. HICKS}

\section{R. F. G. BARRIER*}

Department of Biological Sciences

University of Waikato

Private Bag 3105

Hamilton, New Zealand

*Present address: National Institute of Water \& Atmospheric Research Ltd, P.O. Box 11-115, Hamilton, New Zealand

\begin{abstract}
Black mudfish (Neochanna diversus) were found at 39 of 80 sites in the Waikato region, New Zealand, ranging from large wetlands to small swampy streams. Of the sites with mudfish, $87 \%$ were dry at some time during summer. Sites with mudfish also generally had emergent and overhanging vegetation and tree roots, and showed low to moderate human impact. Black mudfish coexisted at some sites with juvenile eels or mosquitofish, but were absent from all sites with common bullies (Gobiomorphus cotidianus) or inanga (Galaxias maculatus). Sites with mudfish had almost exclusively semi-mineralised substrates or peat; only one site had mineralised substrate. Geometric mean catch rate for the 39 sites with mudfish was 0.70 fish per trap per night. Mean summer water depth was only $2.1 \mathrm{~cm}$ at sites with mudfish, compared to $22.6 \mathrm{~cm}$ at 41 sites without. Winter and maximum water depths were also less at sites with mudfish than at sites without mudfish. Mean turbidity was 11.5 nephelometric turbidity units (NTU) at sites with mudfish, but $21.3 \mathrm{NTU}$ at sites without mudfish. Mudfish catch rates were negatively correlated with summer water depth, winter water depth, disturbance scale rating, and turbidity. A discriminant function model based on
\end{abstract}

M95047

Received 24 July 1995; accepted 24 November 1995 these variables successfully predicted $95 \%$ of the sites with mudfish. Habitat preference curves are also presented.

Keywords black mudfish; Galaxiidae; eels; Neochanna diversus; habitat requirements; mosquitofish; wetlands

\section{INTRODUCTION}

The genus Neochanna (Family Galaxiidae, Order Salmoniformes) is endemic to New Zealand (Nelson 1984), and has three species (McDowall 1990): the black mudfish- $N$. diversus, the brown mudfish - N. apoda, and the Canterbury mudfish $N$. burrowsius. Black mudfish occur in the upper half of the North Island, from Kaitaia in the north to the upper reaches of the Mokau River, northern Taranaki, in the south. They are small, usually reaching a total length (TL) of $90 \mathrm{~mm}$, though one $142 \mathrm{~mm}$ fish has been recorded (McDowall 1990). The fish are elongate, and like the brown mudfish, lack pelvic fins. Spawning takes place in winter, beginning with the onset of the wet season, frequently in May or June. In Redoubt Creek (map coordinates 922 358, Department of Lands and Survey 1978), juveniles were seen in their greatest numbers between mid August and mid September (Thompson 1987). The smallest free-swimming larvae found were $8-9 \mathrm{~mm}$ TL. Sexual maturity is reached at the end of their first year, when mudfish may be only $70 \mathrm{~mm}$ long (Thompson 1987; McDowall 1990); the smallest sexually mature black mudfish recorded was a $53 \mathrm{~mm}$ TL male (McLea 1986). Fecundity is related to size of fish. The regression equation describing fecundity for female black mudfish in the Lake Rotokawau wetland is: $F=-1080+17.8 \mathrm{TL}$, where $\mathrm{F}$ is the number of ova in stage 2 and 3 fish, and TL is the total length in $\mathrm{mm}\left(N=9, r^{2}=0.884\right.$ : McLea 1986). Fecundity of a $100 \mathrm{~mm}$ female is about 700 eggs, which is intermediate between the fecundity of $100 \mathrm{~mm}$ females of brown mudfish ( 275 eggs: 


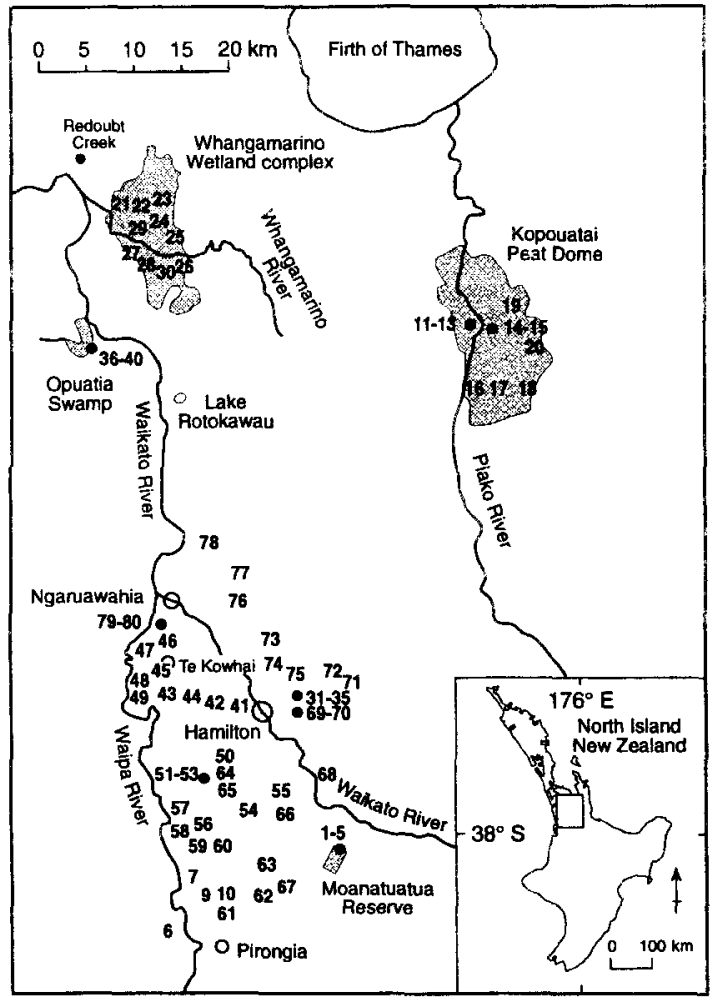

Fig. 1 Locations of sampling sites for black mudfish in the Waikato region. Solid dots are locations of combined sites; open circles are locations of towns and cities.

Eldon 1978) and the Canterbury mudfish (2000 eggs: Eldon 1979a). We found the two sexes of black mudfish to be indistinguishable externally. In captivity, fish may live up to 8 years (Thompson 1987). The primary foods of black mudfish in the Lake Rotokawau wetland were ostracods, oligochaetes, chironomids, copepods, and cladocerans (McLea 1986). Adults are primarily nocturnal (Thompson 1987).

The primary habitats of black mudfish are wetlands, drains, and swampy streams with still and gently flowing waters. Discovered in the 1940s, nothing is known about the species' previous abundance; however, the distribution of black mudfish has almost certainly been affected by the drainage of New Zealand's once-extensive wetlands. Like many native fishes in New Zealand, black mudfish are probably much less widespread than they were before human settlement. Steady declines in black mudfish numbers resulting from land development, drain clearance, and the use of herbicides have been reported (McDowall 1990). Interactions with other swamp-dwelling fish, such as eels (Anguilla spp.), and the introduced mosquitofish (Gambusia affinis), may also affect the mudfish distribution. The spawning of black mudfish, their growth, feeding, and behaviour have been briefly described (Thompson 1987). Extensive wetlands such as the Whangamarino Wetland complex, that occur in the Waikato region, are known strongholds of this species (Strickland 1980; Town 1981).

Because so many of its habitats have been modified or are under threat of modification, and because so little is known about the black mudfish, it has been classified as a species of "indeterminate status" by the International Union for the Conservation of Nature (McDowall 1990). The aim of the present study was to investigate its habitat and other fish species associated with it. The objectives were:

1) to measure physical and water quality variables that define the range of black mudfish;

2) to investigate the effect of seasonal variation of water level on the distribution of black mudfish; and

3) to investigate the association of other fish species with black mudfish, especially the mosquitofish (Barrier 1993).

\section{METHODS}

\section{Study sites}

We sampled a range of habitat types in the Waikato region, based on where black mudfish had been previously found (e.g., McLea 1986; Thompson 1987; Freshwater Fisheries Database, National Institute of Water \& Atmospheric Research Ltd). Of the 80 sites, 31 were located in drains, 30 in wetlands, swamps, and a peat dome, 9 in swampy streams, 6 in lake margins, and 4 in ponds, dams, or lagoons (Fig. 1, Table 1). We excluded fastflowing streams and rivers, and open water sites with a mean winter depth $>1.5 \mathrm{~m}$. Trapping sites were pre-selected during summer and autumn (January-May), and the dry-season data were collected then. Dry summer-like conditions extended into May in 1992. Sites were chosen in two extensive wetlands, the Kopouatai Peat Dome (9000 ha: Sites 11-20), and the Whangamarino Wetland complex (7700 ha: Sites 21-30). The Opuatia Swamp (800 ha: Sites 36-40), the small 
Table 1 Site numbers, map numbers, and map coordinates of sites sampled for black mudfish in the Waikato region, showing presence $(+)$ or absence $(-)$ of mudfish. Map numbers refer to Department of Lands and Survey $(1979,1980)$.

\begin{tabular}{|c|c|c|c|c|c|}
\hline \multirow[b]{2}{*}{ Site no. } & \multirow{2}{*}{$\begin{array}{c}\text { Mudfish } \\
\text { present }\end{array}$} & \multirow[b]{2}{*}{ Map no. } & \multicolumn{2}{|c|}{ Map coordinates } & \multirow[b]{2}{*}{ Site description } \\
\hline & & & Eastings & Northings & \\
\hline 1 & - & S15 & 184 & 623 & Boundary drain, Moanatuatua Reserve \\
\hline 2 & _- & S15 & 183 & 619 & Boundary drain, Moanatuatua Reserve \\
\hline 3 & - & S15 & 190 & 622 & Boundary drain, Moanatuatua Reserve \\
\hline 4 & - & S15 & 190 & 621 & Boundary drain, Moanatuatua Reserve \\
\hline 5 & _ & S15 & 190 & 619 & Boundary drain, Moanatuatua Reserve \\
\hline 6 & - & S15 & 028 & 536 & Small wetland \\
\hline 7 & - & S15 & 044 & 603 & Swampy stream \\
\hline 8 & _- & S15 & 053 & 607 & Lake Mangakawa margin \\
\hline 9 & - & S15 & 058 & 575 & Roadside drain \\
\hline 10 & - & S15 & 061 & 574 & Large flowing drain \\
\hline 11 & - & T13 & 335 & 199 & Kopouatai Peat Dome \\
\hline 12 & + & T13 & 340 & 197 & Kopouatai Peat Dome \\
\hline 13 & + & T13 & 339 & 197 & Kopouatai Peat Dome \\
\hline 14 & + & T13 & 345 & 198 & Kopouatai Peat Dome \\
\hline 15 & - & T13 & 346 & 187 & Kopouatai Peat Dome \\
\hline 16 & - & T13 & 342 & 120 & Kopouatai Peat Dome \\
\hline 17 & + & T13 & 344 & 120 & Kopouatai Peat Dome \\
\hline 18 & + & T13 & 409 & 128 & Kopouatai Peat Dome \\
\hline 19 & + & $\mathrm{T} 13$ & 383 & 194 & Kopouatai Peat Dome \\
\hline 20 & - & T13 & 408 & 183 & Kopouatai Peat Dome pond \\
\hline 21 & + & S13 & 950 & 307 & Whangamarino Wetland drain \\
\hline 22 & + & S13 & 979 & 319 & Whangamarino Wetland \\
\hline 23 & - & $\mathrm{S} 13$ & 963 & 312 & Whangamarino Wetland \\
\hline 24 & + & S13 & 012 & 294 & Whangamarino Wetland \\
\hline 25 & + & S13 & 027 & 287 & Whangamarino Wetland \\
\hline 26 & - & $\mathrm{S} 13$ & 032 & 262 & Whangamarino Wetland \\
\hline 27 & + & $\mathrm{S} 13$ & 014 & 262 & Whangamarino Wetland \\
\hline 28 & + & $\mathrm{S} 13$ & 009 & 263 & Whangamarino Wetland \\
\hline 29 & + & S13 & 003 & 267 & Whangamarino Wetland \\
\hline 30 & + & S13 & 022 & 262 & Whangamarino Wetland \\
\hline 31 & - & S14 & 160 & 790 & Roadside drain \\
\hline 32 & + & S14 & 160 & 790 & Roadside drain \\
\hline 33 & - & S14 & 163 & 795 & Roadside drain \\
\hline 34 & + & S14 & 152 & 782 & Roadside drain \\
\hline 35 & + & $\mathrm{S} 14$ & 149 & 783 & Roadside drain \\
\hline 36 & + & S13 & 938 & 174 & Opuatia Swamp \\
\hline 37 & + & $\mathrm{S} 13$ & 937 & 174 & Opuatia Swamp \\
\hline 38 & + & $\mathrm{S} 13$ & 938 & 163 & Opuatia Swamp \\
\hline 39 & + & S13 & 937 & 163 & Opuatia Swamp \\
\hline 40 & - & $\mathrm{S} 13$ & 936 & 153 & Opuatia Swamp \\
\hline 41 & - & S14 & 085 & 786 & Forest Lake margin \\
\hline 42 & - & S14 & 063 & 787 & Horseshoe Lake inflow drain \\
\hline 43 & - & $\mathrm{S} 14$ & 005 & 804 & Farm drain \\
\hline 44 & - & $\mathrm{S} 14$ & 039 & 796 & Lake Rotokauri drain \\
\hline 45 & + & $\mathrm{S} 14$ & 001 & 824 & Roadside wetland \\
\hline 46 & + & S14 & 003 & 855 & Swampy stream \\
\hline 47 & - & $\mathrm{S} 14$ & 981 & 849 & Te Otomanui Lagoon \\
\hline 48 & + & S14 & 979 & 807 & Swampy stream \\
\hline 49 & - & S14 & 975 & 792 & Lagoon \\
\hline 50 & + & $\mathrm{S} 14$ & 090 & 725 & Roadside drain \\
\hline 51 & - & $\mathrm{S} 14$ & 051 & 702 & Lake Posa margin \\
\hline 52 & - & S14 & 053 & 701 & Lake Pataka drain \\
\hline 53 & - & S14 & 053 & 704 & Lake Pataka margin \\
\hline
\end{tabular}


Table 1 (continued).

\begin{tabular}{|c|c|c|c|c|c|}
\hline \multirow[b]{2}{*}{ Site no. } & \multirow{2}{*}{$\begin{array}{c}\text { Mudfish } \\
\text { present }\end{array}$} & \multirow[b]{2}{*}{ Map no. } & \multicolumn{2}{|c|}{ Map coordinates } & \multirow[b]{2}{*}{ Site description } \\
\hline & & & Eastings & Northings & \\
\hline 54 & - & $\mathrm{S} 15$ & 098 & 674 & Swampy roadside drain \\
\hline 55 & - & S15 & 126 & 694 & Lake Cameron margin \\
\hline 56 & + & S15 & 042 & 654 & Swampy stream \\
\hline 57 & + & S 15 & 020 & 673 & Stream in swampy gully \\
\hline 58 & + & S15 & 015 & 659 & Stream in swampy gully \\
\hline 59 & + & S15 & 047 & 629 & Mangaotama Stream \\
\hline 60 & + & S15 & 036 & 623 & Swampy stream \\
\hline 61 & - & S15 & 068 & 559 & Farm drain \\
\hline 62 & - & S15 & 117 & 578 & Lake Ngaroto drain \\
\hline 63 & - & $\mathrm{S} 15$ & 116 & 613 & Lake Ruatuna margin \\
\hline 64 & + & S 15 & 836 & 730 & Roadside drain \\
\hline 65 & + & $\mathrm{S} 14$ & 076 & 702 & Roadside drain \\
\hline 66 & + & S15 & 138 & 664 & Farm drain \\
\hline 67 & - & $\mathrm{S} 15$ & 131 & 586 & Stock water dam \\
\hline 68 & - & $\mathrm{S} 14$ & 173 & 704 & Wetland, Narrows golf course \\
\hline 69 & + & S14 & 159 & 788 & Roadside drain \\
\hline 70 & + & $\mathrm{S} 14$ & 161 & 789 & Roadside drain \\
\hline 71 & - & $\mathrm{S} 14$ & 199 & 802 & Roadside drain \\
\hline 72 & - & S14 & 189 & 815 & Roadside drain \\
\hline 73 & - & S14 & 120 & 822 & Small wetland \\
\hline 74 & - & $\mathrm{S} 14$ & 123 & 814 & Small wetland \\
\hline 75 & - & $\mathrm{S} 14$ & 137 & 816 & Roadside drain \\
\hline 76 & - & $\mathrm{S} 14$ & 079 & 897 & Lake D drain \\
\hline 77 & + & S14 & 082 & 920 & Roadside drain \\
\hline 78 & + & S14 & 058 & 947 & Mangatoketoke Stream \\
\hline 79 & + & $\mathrm{S} 14$ & 002 & 866 & Roadside wetland \\
\hline 80 & + & S14 & 998 & 864 & Roadside wetland \\
\hline
\end{tabular}

Moanatuatua Scientific Reserve (70 ha: sites 1-5), and drains, lakes, and wet areas around Hamilton, Pirongia, Te Kowhai, and Ngaruawahia were also sampled (Fig. 1).

The Kopouatai Peat Dome is the last of the lowland raised bogs in the North Island that is still almost intact. It has a unique bog vegetation, dominated by restiad rushes (Family Restionaceae), especially the giant rush Sporodanthus traversii, and its vegetation and hydrology have been minimally disturbed. The Whangamarino Wetland complex contains one of the last remaining areas of unmodified peatland in the Waikato region. The wetland is low-lying, the highest point being only $7 \mathrm{~m}$ above sea level. Parts of the swamp are clear of dense tree vegetation, and these areas usually have rush or sedge communities, interspersed with manuka (Leptospermum scoparium). The Opuatia Swamp is similar to the Whangamarino Wetland complex in many aspects, but is much smaller in size; it also has more mineralised areas than the
Whangamarino Wetland complex, and appears to be drier in summer. Areas of kahikatea (Dacrycarpus dacrydioides) and tawa (Beilschmiedia tawa) forest are also present in the Opuatia Swamp.

The Moanatuatua Scientific Reserve is a remnant of native peatland vegetation in the Waikato Basin. It has unnatural straight boundaries produced by agricultural drainage, which take no account of natural zonation of the vegetation. The reserve supports an acid peat bog community similar to the Kopouatai Peat Dome. Much of the reserve is rushland dominated by the restiad rushes Sporodanthus traversii and Empodisma minus. Drainage and subsequent sinking of surrounding peat farmland have dewatered the reserve, and the only water now present is in the surrounding drains.

The drains investigated ranged from recently cleaned, steep-walled drains, to low-relief, wellvegetated drains. Streams draining small pockets of swamp, and lake fringes, or their outflowing streams or drains, were also sampled (Table 1). 


\section{Habitat associations}

Fish were trapped between 20 May and 21 October 1992, and wet-season data were collected then. Trapping over the dry summer months was not done as many sites had only damp mud with no surface water at that time. To encompass the range of habitat conditions that would support mudfish, approximately equal numbers of sites with and without mudfish were chosen.

Fish were caught using five fine-mesh Gee minnow traps set once at each site for about $24 \mathrm{~h}$, resting on the substrate. The traps had wire mesh that created square holes $3 \mathrm{~mm}$ by $3 \mathrm{~mm}$, and the conical entrances at the two ends of each trap were $25 \mathrm{~mm}$ in diameter. The traps themselves were 220 $\mathrm{mm}$ in diameter and $410 \mathrm{~mm}$ long, and were constructed of two halves that clipped together in the centre. In shallow water, care was taken to fully submerge the trap entrance while leaving an air space at the top of the trap. Otherwise, in low oxygen conditions where mudfish have to surface to breathe air, trapping could kill them. The spacing of traps at each site was approximately uniform over an area of $25 \mathrm{~m}^{2}$ wherever possible to give a comparable catch per unit effort. Traps were set between $1000 \mathrm{~h}$ and $1400 \mathrm{~h}$, left overnight to fish, and picked up about the same time on the following day. Traps were initially baited, but since there was no obvious difference in catch rates between baited and unbaited traps, baiting was discontinued. The mudfish caught were weighed and their length was measured, whereupon they were returned to their point of capture. At sites with many small mudfish, a subsample was weighed.

A range of habitat variables that were anticipated to influence mudfish distribution were measured (Table 2). Some habitat variables were measured in summer, whereas others could only be measured in winter. Sites were selected and summer water depths were measured in the driest parts of the year (between January and March 1992) where traps were to be positioned. Sites that were dry were recorded as having zero water depth. Other habitat variables, including winter depth where traps were positioned, maximum water depth, surface water velocity, dissolved oxygen, and total dissolved solids were measured in the field between June and October 1992 (Table 2).

Some water quality variables were determined in the laboratory: water samples collected from each site were kept cool during transit, and analysed within $8 \mathrm{~h}$ of collection for $\mathrm{pH}$ and conductivity, and within $72 \mathrm{~h}$ for turbidity and humic concentration (Table 2). To measure humic content, light absorbance of membrane-filtered (Sartorius $0.2 \mu \mathrm{m}$ ) water samples was measured by spectrophotometer in glass cuvettes of $10 \mathrm{~mm}$ path length. Absorbance was measured at $440 \mathrm{~nm}$ versus a distilled water control. Humic concentration $\left(\mathrm{A}_{440} \mathrm{~m}^{-1}\right)$, was then calculated using the following equation:

$\mathrm{A}_{440} \mathrm{~m}^{-1}=230.3 \mathrm{~A}_{440}$,

where $A_{440}=$ absorbance at $440 \mathrm{~nm}$ (Vant \& Davies-Colley 1984).

The vegetation at each site was used to rank sites on a 5-point scale (Table 3). The vegetation reflected both the influence of invasive exotic plants, and the extent of human disturbance. Vegetation indicative of extent of disturbance for the 80 sites sampled were restiad rushes (Sporodanthus traversii and Empodisma minus), manuka, pussy willow (Salix x reichardtii), Yorkshire fog (Holcus lanatus), and the sweetgrasses Glyceria maxima (reed sweetgrass) and G. fluitans (floating sweetgrass). Direct alteration was defined as a visible change of the substrate or vegetation resulting from activities such as drain digging,

Table 2 Habitat variables, their units, and instruments used to measure them.

\begin{tabular}{lllll}
\hline Habitat variable & Units & Abbreviation & Method of measurement & Where measured \\
\hline Summer water depth & $\mathrm{cm}$ & SWD & Metre ruler or weighted string & Field \\
Winter water depth & $\mathrm{cm}$ & WWD & Metre ruler or weighted string & Field \\
Maximum water depth & $\mathrm{cm}$ & MWD & Metre ruler or weighted string & Field \\
Total dissolved solids & $\mathrm{g} \mathrm{m}^{-3}$ & TDS & Portable Hanna meter, model HI 8734 & Field \\
Surface dissolved oxygen & $\mathrm{g} \mathrm{m}^{-3}$ & SDO & YSI oxygen meter, model 57 & Field \\
Surface water velocity & $\mathrm{m} \mathrm{s}^{-1}$ & SWV & Distance object floated in given time & Field \\
Turbidity & $\mathrm{NTU}$ & TUR & Hach Portalab turbidimeter, model 16800 & Laboratory \\
Conductivity & $\mu S \mathrm{~cm}$ & CON & Philips P W conductivity meter, model 9505 Laboratory & Laborat \\
pH & $\mathrm{pH} \mathrm{units}$ & PH & Orion Research Digital Ionalyzer, model 501 Laboratory \\
Humic concentration & $\mathrm{A}_{440} \mathrm{~m}^{-1}$ & $\mathrm{HC}$ & Shimadzu spectrophotometer, model UV 250 Laboratory \\
\hline
\end{tabular}


dam construction, or tree felling. Indirect alteration was defined as change from the natural state that had been precipitated elsewhere, such as degradation of water quality as a result of human activity.

Types of cover potentially important for mudfish were recorded for each site. These were emergent, submerged, and overhanging vegetation; submerged woody debris; and tree roots. Cover types were recorded as being present only if they occupied more than $20 \%$ of the available habitat; this was to prevent one or two scattered plants being classified as significant fish cover. For example, overhanging vegetation was classified as any vegetation, such as trees or rushes, that overhung more than $20 \%$ of water surface over the area trapped. Plant species providing cover were identified and recorded and samples of unknown species taken to the laboratory for identification.

Wetland surface substrate types can be broadly classified according to vegetation patterns and their appearance, and may be organic, mineral, or a mixture of both. These are the substrates in contact with the water, as distinct from the underlying soil types, which are exclusively mineral. The substrate at each site was classified as mineralised, semimineralised, or peat bog according to the criteria of Humphreys (1991). The peat bogs receive most, if not all, of their water from rainfall and have low $\mathrm{pH}$. They therefore have low fertility compared with surrounding areas affected by floodwater from rivers. Peat bogs were characterised by areas covered in native rushes and manuka that are adapted to acidic, waterlogged conditions. Semimineralised substrates were areas of predominantly organic peat that received inputs of silt and nutrients from floodwaters. Pussy willow occupied nearly all of these areas. Mineralised areas adjoined the river channels. The substrate in mineralised areas was dominated by river silt, and with a $\mathrm{pH}$ of around 7 was more fertile than peat substrates. Mineralised substrates were characterised by herb meadows and crack willow (Salix fragilis). Source of flood water (whether from rivers and rainfall, or from rainfall alone) was recorded.

The soil type underlying each site was determined from 1:250,000 scale soil maps (DSIR 1954). Though dated, these were the only maps available showing soil types throughout the entire study region. Categories of underlying soil type used were:

1 -organic group

2 -yellow-brown loam subgroup

3 - brown granular clay subgroup

4 recent group (from alluvium)

5-meadow group.

Categories 2 and 3 are both subgroups of the brown loam group.

\section{Data analysis}

To determine the variables associated with black mudfish, we divided the data into two groups, categorising sites as those with black mudfish, and those without. The significance of associations between the presence or absence of black mudfish and categorical variables was tested using $\chi^{2}$ tests of independence (Wilkinson et al. 1994). We chose variables for the discrimant function model using univariate analysis of variance (ANOVA) and correlation analysis. For each continuous habitat variable, we used ANOVA to determine those variables with significantly different means for each group. For catch rates, geometric means were calculated in preference to arithmetic means because of the positive skew of the catch rate data. Geometric means were calculated from the arithmetic means of natural-log transformed data. Spearman's rank correlation coefficients $(\rho)$ were

Table 3 Vegetative characteristics used to determine disturbance scale rating and to rank sites for extent of modification. $N$, number of sites.

\begin{tabular}{|c|c|c|c|c|c|c|c|c|}
\hline \multirow[b]{2}{*}{$\begin{array}{l}\text { Disturbance } \\
\text { scale } \\
\text { rating }\end{array}$} & \multicolumn{5}{|c|}{ Proportion of sites with key vegetation species } & \multirow[b]{2}{*}{$N$} & \multirow[b]{2}{*}{$\begin{array}{l}\text { Importance } \\
\text { of native } \\
\text { vegetation }\end{array}$} & \multirow[b]{2}{*}{$\begin{array}{l}\text { Extent of } \\
\text { physical } \\
\text { alteration }\end{array}$} \\
\hline & $\begin{array}{l}\text { Restiad } \\
\text { rushes }\end{array}$ & Manuka & $\begin{array}{c}\text { Pussy } \\
\text { willow }\end{array}$ & $\begin{array}{c}\text { Yorkshire } \\
\text { fog }\end{array}$ & $\begin{array}{c}\text { Sweetgrass } \\
\text { species }\end{array}$ & & & \\
\hline 1 & 0.40 & 0.60 & 0.00 & 0.00 & 0.00 & 5 & Very high & None \\
\hline 2 & 0.60 & 0.80 & 0.40 & 0.00 & 0.00 & 5 & High & Indirect \\
\hline 3 & 0.00 & 0.20 & 0.90 & 0.10 & 0.00 & 10 & Medium to low & Indirect \\
\hline 4 & 0.00 & 0.14 & 0.52 & 0.40 & 0.26 & 35 & Low & Direct $(>1$ year ago) \\
\hline 5 & 0.00 & 0.00 & 0.04 & 0.48 & 0.04 & 25 & Very low & Direct $(0-1$ year ago $)$ \\
\hline
\end{tabular}


calculated for the catch rate of mudfish (number of fish caught per trap per overnight set) and each continuous habitat variable.

Habitat preference curves were determined for summer and winter water depth, disturbance, and turbidity. Habitat preference for each variable was calculated from the mean catch rates for intervals within each variable, normalised by scaling to a maximum preference value of 1 by dividing each catch rate by the maximum catch rate. Preference for winter water depth of $0 \mathrm{~cm}$ was assumed to be zero. Smoothed curves were drawn through the preference data using a third-degree polynomial fitted piecewise to the points.

Discriminant function analysis (Wilkinson et al. 1994) was used, based on the two groups of sites defined above, to test the classification of sites by the selected habitat variables. From the two classification functions that were calculated, the correlations of the continuous variables and the factor scores were investigated. The purpose of this analysis was to produce a model that would predict whether or not sites were capable of supporting black mudfish. A canonical discriminant function was produced that was used to test the accuracy of predictions made by the analysis.

\section{RESULTS}

A total of 222 black mudfish were caught in the 400 traps set between May and October 1992. Mean TL was $67 \mathrm{~mm}$ (range 26-139 mm, $N=214$ ).
To increase the range for the weight-length regression, data for an additional 70 mudfish sampled from Site 32 in December and May 1993 (length range $26-157 \mathrm{~mm}$ ) were added to the 154 weights and lengths from the May-October 1992 sampling. The weight-length regression equation was: $\ln (W)=-12.15+3.01 \ln (T L)$, where $\ln (W)$ is the natural logarithm of weight in $g$, and $\ln (\mathrm{TL})$ is the natural logarithm of total length in $\mathrm{mm}(N=$ $224, r^{2}=0.962, P<0.001$ ).

Of the 80 sites sampled, 39 had black mudfish. Mudfish were not distributed uniformly among the habitat types ( $\chi^{2}$ test of independence, $P<0.001$ : Table 4); mudfish were found at 8 out of 9 swampy stream sites, and at 20 out of 30 wetland sites. However, they were found at only 11 out of 31 drain sites, and none of the 6 lake margin or 4 pond, dam, and lagoon sites. Categorical variables that distinguished the sites with mudfish from those without ( $\chi^{2}$ tests of independence, $P<0.05$ : Table 4) were:

1. absence of water in summer (of sites with mudfish, $87 \%$ were dry at some point over summer);

2. low to moderate disturbance scale rating;

3. presence of emergent and overhanging vegetation;

4. semi-mineralised or peat bog substrate types;

5. absence of fish species such as common bullies (Gobiomorphus cotidianus) and inanga (Galaxias maculatus); and

6. presence of tree roots.

Table $4 \quad \chi^{2}$ tests of association between presence or absence of black mudfish and categorical habitat variables at sites in the Waikato region.

\begin{tabular}{lccc}
\hline $\begin{array}{l}\text { Habitat } \\
\text { variable }\end{array}$ & $\begin{array}{c}\chi^{2} \\
\text { statistic }\end{array}$ & $\begin{array}{c}\text { Degrees of } \\
\text { freedom }\end{array}$ & Probability \\
\hline Habitat type & 21.35 & 4 & $<0.001$ \\
Absence of water in summer & 31.84 & 1 & $<0.001$ \\
Disturbance scale rating & 23.92 & 4 & $<0.001$ \\
Emergent vegetation & 17.56 & 1 & $<0.001$ \\
Overhanging vegetation & 11.82 & 1 & $<0.001$ \\
Surface substrate type & 16.51 & 2 & $<0.001$ \\
Absence of common bullies & & & \\
$\quad$ and inanga & 6.17 & 1 & 0.013 \\
Tree roots & 4.00 & 1 & 0.045 \\
Underlying soil type & 8.05 & 4 & 0.090 \\
Flood source & 2.98 & 1 & 0.084 \\
Submerged woody debris & 2.55 & 1 & 0.111 \\
Submerged vegetation & 0.440 & 1 & 0.507 \\
Juvenile eels & 0.478 & 1 & 0.489 \\
Mosquitofish & 0.200 & 1 & 0.655 \\
\hline
\end{tabular}


The distribution of mudfish was not significantly associated with the underlying soil type, flood source, submerged woody debris, or submerged vegetation ( $\chi^{2}$ tests of independence, $P \geq 0.090$ : Table 4). Also, black mudfish coexisted with juvenile eels and mosquitofish $(P \geq 0.489$ : Table 4$)$.

Means of the continuous variables summer water depth, winter water depth, turbidity, and maximum water depth were significantly different between sites with and without mudfish ( $t$-test, $P \geq 0.016$ : Table 5). Mean summer water depth was only $2.1 \mathrm{~cm}$ at sites with mudfish, compared to $22.6 \mathrm{~cm}$ at sites without. Winter and maximum water depths were also less at sites with mudfish than at sites without mudfish. Mean turbidity was 11.5 nephelometric turbidity units (NTU) at sites with mudfish, but 21.3 NTU at sites without mudfish. Conductivity, total dissolved solids, dissolved oxygen at the water surface, humic concentration, $\mathrm{pH}$, and water velocity were similar at all sites ( $t$-test, $P \geq 0.153$ : Table 5). Catch rates at sites with mudfish were $0.2-8.4$ mudfish per trap per night (geometric mean 0.70: Table 5).

Catch rates for classes within variables, and the habitat preference curves calculated from these, show that mudfish were virtually absent from water of $>30 \mathrm{~cm}$ depth in summer (Fig. 2). However, in winter mudfish preferred water depths between 15 and $50 \mathrm{~cm}$. Disturbance scale ratings of 3 were preferred, as were turbidities of $<15$ NTU. Preference for the DSR of 1 was assumed to be the same as for the DSR of 2, as the small number of sites with DSR of 1 and $2(N=5$ in each case) made their separate preferences unreliable.

Considering all sites together, catch rates of mudfish (i.e., number of fish per trap per night) were significantly negatively correlated with both summer water depth and disturbance scale rating (Spearman's $\rho \leq 0.58, P<0.001$ : Table 6). Correlations were also significant between catch rate of mudfish and winter depth, maximum depth, and turbidity (Spearman's $\rho \leq 0.26, P<0.005$ ). On the basis of the univariate ANOVA (Table 5), and the correlation analysis (Table 6), the variables summer water depth, winter water depth, disturbance scale rating, and turbidity were chosen for the discriminant function analysis. Because correlations between summer depth and winter and maximum depth were also high (Spearman's $\rho=$ $0.50, P<0.001$ ), maximum depth was excluded from the analysis. Winter water depth was a necessary variable, despite its high correlation with summer water depth, because it described the presence of water for the winter stage of the mudfish life cycle.

A discriminant function classification based on the two groups of sites with and without mudfish was determined using the variables summer water depth, winter water depth, disturbance scale rating, and turbidity. Two classification functions were used to classify sites into groups, with each site classified into the group with the largest value of

Table 5 Means $\pm 95 \%$ confidence intervals (CI) and standard deviations (SD) of continuous variables at sites with black mudfish $(\mathrm{N}=39)$ and without black mudfish $(\mathrm{N}=41)$ in the Waikato region. Probability of similarity of means tested with $t$-test. Mudfish catch rate shown is a geometric mean.

\begin{tabular}{|c|c|c|c|c|c|}
\hline \multirow[b]{2}{*}{ Variable } & \multicolumn{2}{|c|}{ Sites with mudfish } & \multicolumn{2}{|c|}{ Sites without mudfish } & \multirow[b]{2}{*}{ Probability } \\
\hline & Mean $\pm \mathrm{CI}$ & $\mathrm{SD}$ & Mean $\pm \mathrm{CI}$ & SD & \\
\hline $\begin{array}{l}\text { Mudfish catch rate } \\
\text { (fish per trap per night) }\end{array}$ & $0.70 \pm 1.31$ & 0.84 & 0.00 & & \\
\hline Summer water depth $(\mathrm{cm})$ & $2.1 \pm 1.9$ & 2.2 & $22.6 \pm 7.8$ & 24.7 & $<0.001$ \\
\hline Winter water depth $(\mathrm{cm})$ & $28.9 \pm 4.3$ & 5.8 & $40.2 \pm 7.7$ & 24.4 & 0.012 \\
\hline Turbidity (NTU) & $11.5 \pm 2.5$ & 13.3 & $21.3 \pm 7.1$ & 22.6 & 0.012 \\
\hline Maximum water depth $(\mathrm{cm})$ & $45.4 \pm 7.0$ & 7.7 & $78.6 \pm 25.6$ & 81.0 & 0.016 \\
\hline Conductivity $\left(\mu \mathrm{S} \mathrm{cm}^{-1}\right)$ & $88.1 \pm 12.9$ & 21.6 & $104.0 \pm 17.9$ & 56.6 & 0.153 \\
\hline $\begin{array}{l}\text { Total dissolved solids } \\
\left(\mathrm{g} \mathrm{m}^{-3}\right)\end{array}$ & $59.3 \pm 8.4$ & 39.9 & $66.6 \pm 11.0$ & 34.7 & 0.291 \\
\hline $\begin{array}{l}\text { Surface dissolved oxygen } \\
\left(\mathrm{g} \mathrm{m}^{-3}\right)\end{array}$ & $3.9 \pm 0.8$ & 25.9 & $4.4 \pm 1.0$ & 3.1 & 0.393 \\
\hline $\begin{array}{l}\text { Humic concentration } \\
\left(\mathrm{A}_{440} \mathrm{~m}^{-1}\right)\end{array}$ & $0.072 \pm 0.022$ & 2.423 & $0.061 \pm 0.016$ & 0.052 & 0.429 \\
\hline $\mathrm{pH}$ & $5.7 \pm 0.24$ & 0.07 & $5.9 \pm 0.27$ & 0.86 & 0.432 \\
\hline Water velocity $\left(\mathrm{m} \mathrm{s}^{-1}\right)$ & $0.02 \pm 0.01$ & 0.73 & $0.03 \pm 0.02$ & 0.05 & 0.439 \\
\hline
\end{tabular}



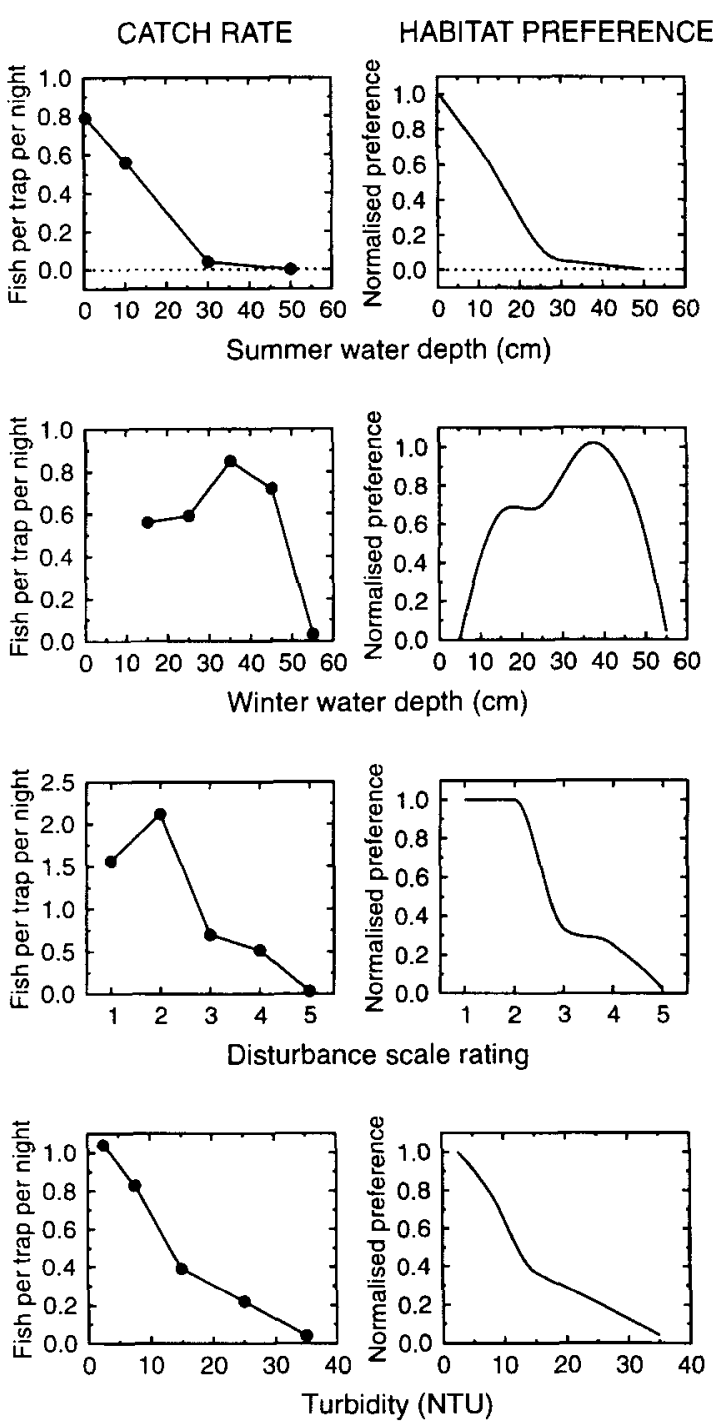

Fig. 2 Catch rates (fish per trap per night) and habitat preferences of black mudfish in the Waikato region for the variables summer water depth, winter water depth, extent of modfication of the vegetation (disturbance scale rating), and turbidity (NTU, nephelometric turbidity units). Criteria for the disturbance scale rating are given in Table 3.

its factor scores, calculated from the classification functions (Fig. 3). Spearman non-parametric correlations among the factor scores and the habitat variables were calculated to look for the underlying variables with most influence on the factors. Factor 1 was highly correlated with disturbance scale rating

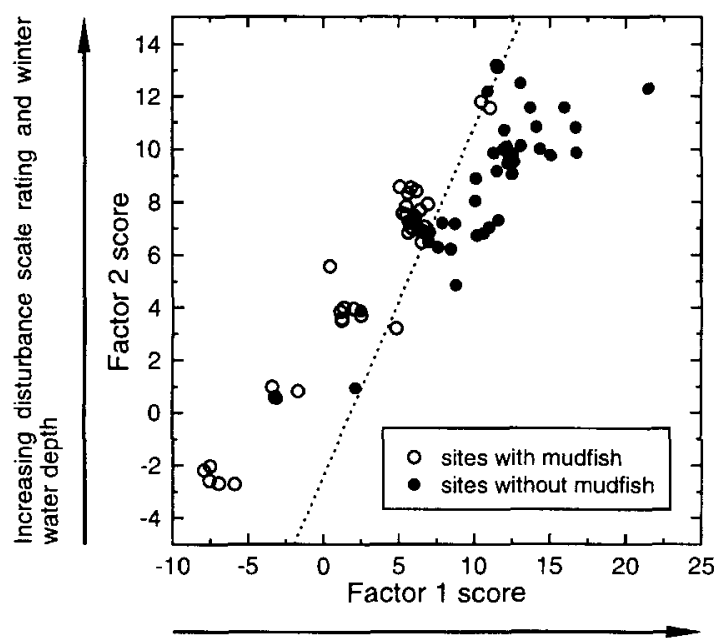

Increasing disturbance scale rating and summer water depth

Fig. 3 Factor scores calculated from classification functions for sites with black mudfish $(N=39)$ and without black mudfish $(N=41)$ in the Waikato region, using the habitat variables summer and winter water depth, disturbance scale rating, and turbidity. The line $y=-2.412+1.324 x$ separates predicted sites with mudfish from those without, where $x=$ Factor 1 and $y=$ Factor 2.

(Spearman's $\rho=0.92, N=80$ ), and with summer water depth (Spearman's $\rho=0.58, N=80$ ). Catch rate of mudfish, though not used in the discriminant function analysis, was negatively correlated with Factor 1 for those sites with mudfish (Spearman's $\rho=0.43, N=39$ ). Factor 2 was also highly correlated with disturbance scale rating (Spearman's $\rho=0.94, N=80$ ), and with winter water depth (Spearman's $\rho=0.60, N=80$ ).

The single canonical discriminant function derived (Table 7A) was used to calculate canonical scores from the unstandardised coefficients (Wilkinson et al. 1994). Sites ranked by their canonical scores were generally successfully separated by the canonical discriminant function (Fig. 4; Appendix 1). Group centroids for the sites with and without mudfish were -1.068 and 1.016 , respectively. The canonical discriminant function was able to correctly predict $95 \%$ of the sites with mudfish, and $83 \%$ of the sites without mudfish (Table 7B). Catch rate of mudfish was highly negatively correlated with the canonical scores for sites with mudfish (Spearman's $\rho=-0.37, N=39$ ). 


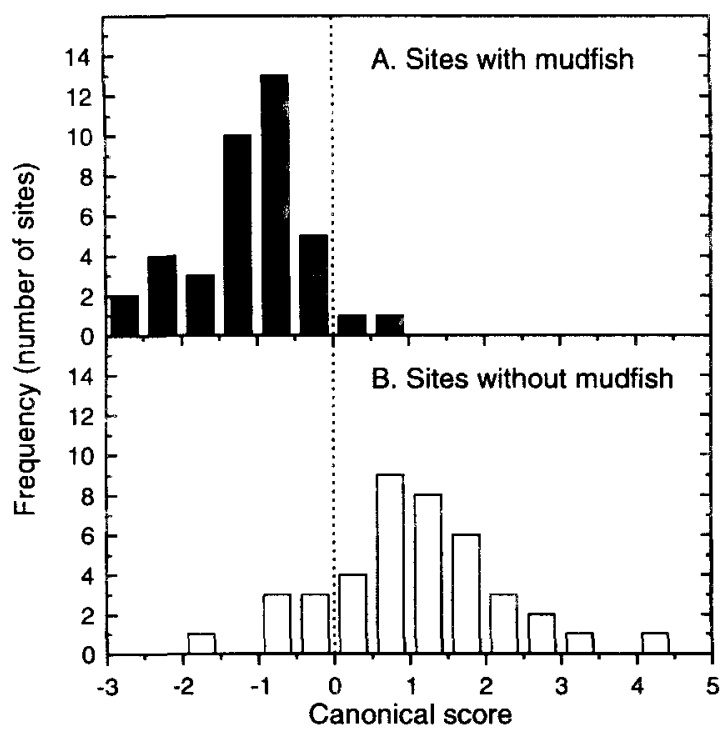

Fig. 4 Frequency of sites classified by the unstandardised canonical discriminant function using the variables summer water depth, winter water depth, disturbance scale rating, and turbidity for each site. Zero is the division point for the separation of sites with and without mudfish.

\section{DISCUSSION}

\section{Habitat and fish associations}

Black mudfish habitat in the Waikato region can be adequately predicted by four variables that are easy to measure: summer water depth, winter water depth, extent of disturbance (as indicated by vegetation), and turbidity. Univariate analyses showed differences in these variables between sites with mudfish and those without, indicating the appropriateness of multivariate analysis. Discriminant function analysis was an effective tool for combining these four variables into a single multivariate model that identified $95 \%$ of sites with mudfish correctly. As we divided the data set into only two groups (i.e., sites with or without mudfish), only one canonical discriminant function resulted. To calculate the canonical score for each site, each variable was multiplied by its unstandardised canonical discriminant function coefficient, as follows:

canonical score $=2.5899+0.0765 \mathrm{SWD}$

-0.0437 WWD +0.6872 DSR + 0.0290 TUR,

where $\mathrm{SWD}=$ summer water depth in $\mathrm{cm}, \mathrm{WWD}=$ winter water depth in $\mathrm{cm}$, DSR = disturbance scale rating determined from Table 3 , and TUR $=$ turbidity in NTU. If the resulting canonical score was $<0$, then the site had mudfish in $95 \%$ of instances, but if the canonical score was $>0$, then the site did not have mudfish in $83 \%$ of instances. The magnitude of the canonical score was strongly negatively correlated with the catch rate, suggesting that for sites with canonical scores $<0$, catch rates of mudfish were greater at sites with lower canonical scores than at those with higher scores.

Catch rates of black mudfish can be extremely high. In the present study, catch rates ranged from 0.2 to 8.4 mudfish per trap per night (geometric mean 0.70) between May and October 1992, and were similar to those of Dean (1995) in September 1993 and October 1994 in the Whangamarino

Table 6 Spearman correlations of catch rate of black mudfish (number of fish per trap-night) in winter and habitat variables $(N=80)$; bold/italic numbers indicate significance $P<0.05$, two tailed (Zar 1984). CR, catch rate of black mudfish (fish per trap per night); DSR, disturbance scale rating (as defined in Table 3); abbreviations for other variables are listed in Table 2 .

\begin{tabular}{llrlrrrrrrrr}
\hline & CR & SWD & DSR & WWD & MWD & TUR & SDO & CON & PH & TDS & SWV \\
\hline SWD & $-\mathbf{0 . 5 9}$ & & & & & & & & & & \\
DSR & -0.58 & $\mathbf{0 . 3 4}$ & & & & & & & & & \\
WWD & $-\mathbf{0 . 2 8}$ & $\mathbf{0 . 5 0}$ & $\mathbf{0 . 3 8}$ & & & & & & & & \\
MWD & $-\mathbf{0 . 2 7}$ & $\mathbf{0 . 5 0}$ & $\mathbf{0 . 3 5}$ & $\mathbf{0 . 8 1}$ & & & & & & & \\
TUR & $-\mathbf{0 . 2 6}$ & -0.10 & $\mathbf{0 . 2 7}$ & -0.01 & -0.13 & & & & & & \\
SDO & -0.07 & $\mathbf{0 . 2 5}$ & $\mathbf{0 . 2 5}$ & $\mathbf{0 . 3 1}$ & $\mathbf{0 . 3 1}$ & -0.23 & & & & & \\
CON & -0.16 & -0.17 & $\mathbf{0 . 2 3}$ & -0.22 & -0.29 & $\mathbf{0 . 4 5}$ & -0.22 & & & & \\
PH & -0.13 & -0.06 & $\mathbf{0 . 0 0}$ & -0.15 & -0.16 & 0.21 & -0.05 & $\mathbf{0 . 4 7}$ & & & \\
TDS & -0.09 & -0.18 & $\mathbf{0 . 2 6}$ & -0.17 & -0.24 & $\mathbf{0 . 4 8}$ & -0.13 & $\mathbf{0 . 9 4}$ & $\mathbf{0 . 4 5}$ & & \\
SWV & -0.08 & 0.03 & $\mathbf{0 . 2 8}$ & 0.15 & 0.11 & -0.05 & $\mathbf{0 . 3 3}$ & 0.05 & -0.05 & 0.04 & \\
HC & 0.02 & -0.22 & -0.09 & -0.12 & -0.05 & 0.05 & -0.30 & -0.23 & -0.31 & -0.25 & -0.27 \\
\hline
\end{tabular}


Wetland complex (0.0-2.0 mudfish per trap per night). The highest mean catch rate in our study, 8.4 mudfish per trap per night, was at Site 24 (Table 1, Fig. 1). The second highest (6.4 mudfish per trap per night) was at Site 32, in a drain about 4 $\mathrm{km}$ east of Hamilton. Subsequent trapping at Site 32 during late November 1992 caught 205 black mudfish of $35-120 \mathrm{~mm}$ total length in three Gee minnow traps, giving a mean catch rate of 68.3 fish per trap per night. One trap in this series caught 89 mudfish (Hicks unpubl. data). Catch rates at Lake Rotokawau were lower (geometric mean 0.12 mudfish per trap per day, range $0.04-0.25$ : McLea 1986). We would expect catches to be representative of abundance regardless of water depth, as a proportion of mudfish in laboratory studies were always benthic (Barrier \& Hicks 1994), and our traps were consistently set on the bottom.

Comparing weight-length regressions, mudfish in our study were consistently lighter for equivalent weights than those in the Lake Rotokawau wetland. The weight-length regression for mudfish in the Lake Rotokawau wetland was

$$
\ln (\mathrm{W})=-11.40+2.89 \ln (\mathrm{TL}),\left(N=70, r^{2}=0.951\right),
$$

Table 7 Discriminant function analysis of sites with and without mudfish using summer water depth, disturbance scale rating, winter water depth, and turbidity. Canonical discriminant function coefficients show unstandardised coefficients used to calculate canonical scores, and standardised coefficients used to show influence of each variable on the canonical score.

\section{A. Canonical discriminant function coefficients}

\begin{tabular}{lcc}
\hline Variable & $\begin{array}{c}\text { Unstandardised } \\
\text { coefficient }\end{array}$ & $\begin{array}{c}\text { Standardised } \\
\text { coefficient }\end{array}$ \\
\hline Summer water depth & 0.0765 & 1.3850 \\
Winter water depth & -0.0437 & -0.8638 \\
Disturbance scale rating & 0.6872 & 0.6803 \\
Turbidity & 0.0290 & 0.4961 \\
Constant & -2.5899 & - \\
\hline
\end{tabular}

\section{B. Classification matrix}

\begin{tabular}{lrrrc}
\hline & $\begin{array}{c}\text { Predicted } \\
\text { present }\end{array}$ & $\begin{array}{c}\text { Predicted } \\
\text { absent }\end{array}$ & Total & $\begin{array}{c}\text { Proportion } \\
\text { correctly } \\
\text { classified }\end{array}$ \\
\hline Mudfish present & 37 & 2 & 39 & $95 \%$ \\
Mudfish absent & 7 & 34 & 41 & $83 \%$ \\
Total & 44 & 36 & 80 & \\
\hline
\end{tabular}

where $\mathrm{W}=$ weight in $\mathrm{g}$ and $\mathrm{TL}=$ total length in $\mathrm{mm}$ (McLea 1986). For mudfish in our study, the regression was

$\ln (\mathrm{W})=-12.15+3.01 \ln (\mathrm{TL})$.

However, McLea's length range (45-110 mm) was considerably smaller than ours, which may account for the difference. The maximum recorded length of black mudfish has been increased from $142 \mathrm{~mm}$ (McDowall 1990) to $157 \mathrm{~mm}$.

Black mudfish in the Waikato region were most commonly found at sites in wetlands with absence of water in summer, moderate depth of water in winter, limited modification of the vegetation (low DSR), and low turbidity (Fig. 2). Habitat preference curves have often been calculated using the normalised ratio of habitat used to habitat availability (Bovee 1986: 118-125). However, the preference values so calculated are identical to those we have calculated from normalised catch rates split into classes for each variable. There are similarities between the habitat requirements of black mudfish and those of brown mudfish and the common river galaxias (Galaxias vulgaris). Brown mudfish inhabited shallow water, sometimes at the edges of deeper water bodies, but were usually absent from water deeper than about 30-50 $\mathrm{cm}$ (Eldon 1978). The common river galaxias also has a preference for shallow water, occupying river margins $<20 \mathrm{~cm}$ deep (Jowett \& Richardson 1995).

Sites where black mudfish were found were not just shallow or dry in summer, but also had substantial seasonal variation in water depth. The coefficients of the standardised canonical discriminant function (where the corresponding scores are standardised to have an overall mean of zero and pooled within-group variances of 1: Table 7A) show that summer water depth, with the largest coefficient, had the greatest influence on the canonical score. Winter water depth had the next highest influence. Turbidity had the least influence on the canonical score of the four variables, but sites with black mudfish had significantly lower turbidity than those without mudfish.

Important in the use of discriminant function analysis is the evaluation of instances that are misclassified. Of the two sites with mudfish that were misclassified, one (Site 25) had a relatively deep summer water depth $(19 \mathrm{~cm})$ and high turbidity (27 NTU: Appendix 1); this site is at the edge of the Whangamarino Wetland complex (Fig. 1). The other (Site 80) had a high disturbance scale rating, 
contrary to that expected of sites with mudfish. Less reliable was classification of sites without mudfish, which were classified correctly in $83 \%$ of instances. Of the 7 sites without mudfish that were misclassified, 4 were dry in summer (Sites 31,42 , 54 , and 68), and the remainder (Sites 40,41, and 55 ) had summer water depths between 6 and $8 \mathrm{~cm}$. All except Site 31 had low to moderate turbidity (7-16 NTU). Sites 55 and 68 had low disturbance scale ratings. No variables external to the model appeared to explain these misclassifications. However, failure to find fish does not prove their absence, and the difficulties in catching mudfish have been documented (Eldon 1992). Low densities of mudfish at some sites where none were caught in our study may account for some of the errors in classification, where habitat was classified as suitable by the canonical score but where no mudfish were found. A weakness of this study is the fact that sites were trapped only once; however, five traps were spread relatively widely at each site to maximise the chance of catching any fish that were there.

Cover was important for black mudfish, in the form of emergent or overhanging vegetation, or tree roots. The significance of cover in determining the presence or absence of black mudfish is predictable, considering the shallow nature of their habitats. Mudfish, though nocturnally active as adults, are likely to require cover during the day to protect them from avian predators, such as bitterns (Botaurus stellaris poiciloptilus) and kingfishers (Halcyon sancta vagans). Predation of black mudfish by a swamp bittern has been recorded (Ogle \& Cheyne 1981). Cover is also important for brown mudfish (Eldon 1978).

Black mudfish were found at sites with the predatory mosquitofish and juvenile eels, and the seasonal drying of their habitats may be a key to the successful coexistence of mudfish with their predators. Mosquitofish are known predators of mudfish fry (Barrier \& Hicks 1994), and eels would presumably also prey on black mudfish, as they do on Canterbury mudfish (Eldon 1979b). Adaptation to marginal wetland habitats that dry seasonally, which must limit the abundance of aquatic predators and competitors of mudfish, may be necessary for the small and otherwise vulnerable mudfish to avoid predation and competition. Black mudfish were absent from the six sites with fish species other than juvenile eels and mosquitofish, such as common bullies and inanga. Sites with mineralised substrate may be avoided because competitors such as common bullies and inanga are present in such sites. The assumption that periodic drying of their habitat excluded competitors of Canterbury mudfish was made by Skrzynski (1968). However, inanga and adult upland bullies (Gobiomorphus breviceps) have been found in the same habitats as Canterbury mudfish (Eldon 1979b). Thus caution should be used in interpreting distributional data in the absence of rigorous tests of the mechanism of competitive exclusion.

If, however, black mudfish are relatively uncompetitive and vulnerable to predation, the question remains as to how they manage to coexist with juvenile eels and mosquitofish. Black mudfish appear to be obligate air breathers under conditions of low $\mathrm{pH}$ combined with high temperatures (Dean 1995). Their adaptations to prolonged respiration in air include wide spacing of secondary gill lamellae and a thin epidermis, compared to these characteristics in a close nonair-breathing relative, the inanga (Dean 1995). Oxygen consumption rates of black mudfish in air were depressed to $15-25 \%$ of the rates in water at the same temperature, showing that metabolic adjustment to aestivation occurs. The $\mathrm{Q}_{10}$ of oxygen consumption was $\mathrm{pH}$-dependent; between 10 and $20^{\circ} \mathrm{C}$ the $\mathrm{Q}_{10}$ was 2.16 at $\mathrm{pH} 7.0$, 1.68 at $\mathrm{pH} 5.5$, and 1.22 at $\mathrm{pH} 4.0$ (Dean 1995). Thus black mudfish are less able to compensate for increasing temperature at low $\mathrm{pH}$ than at circumneutral $\mathrm{pHs}$. As the $\mathrm{pH}$ of their habitats is usually low (mean $\pm 95 \%$ confidence interval $5.7 \pm$ 0.24 , range $4.3-6.7$ in this study: Table 5), black mudfish are probably compelled to leave the water to aestivate as dissolved oxygen concentrations and water levels fall, and as temperature rises. Eldon (1979b) observed the same behaviour in Canterbury mudfish, which left low oxygen water wherever the slope of the bank or container permitted.

Black mudfish do not appear to enter a dormant state while aestivating, despite their metabolic depression, consistent with observations of brown mudfish (Eldon 1978). Two black mudfish uncovered on 18 April 1993 while aestivating in a dry drain near Hamilton (Site 32 ) recovered from their torpor sufficiently to give coordinated swimming movements within 5-10 min of disturbance (Hicks unpubl. data). These data establish that black mudfish can breathe air, just like Canterbury and brown mudfish (Eldon 1978; $1979 \mathrm{~b}$ ). This ability allows mudfish to survive in seasonally dry habitats. 


\section{Management implications}

Our results have implications for the management of black mudfish. The habitat variables measured in this study can be used to classify the suitability of sites for black mudfish in future, using the unstandardised form of the canonical discriminant function we derived (Table 7A). For instance, fire swept through 2000 ha of the Whangamarino Wetland complex in January 1989 (Eldon 1992); the techniques described above could be used to evaluate recovery of the habitat. In wetland habitats, summer absence of water alone was sufficient to classify successfully $87 \%$ of the sites with mudfish, provided that water was present in winter. Of the sites without mudfish, $76 \%$ were correctly classified by the presence of water in summer. However, the discriminant function we describe can improve accuracy in predicting suitable habitat to $95 \%$. Missing from our study, however, is the temporal component of habitat variability. Further work is needed to estimate the length of time that habitats can be dry in summer and wet in winter and still support black mudfish.

The significant negative correlations of black mudfish population catch rate with summer water depth and extent of disturbance (Table 6), and the canonical scores, have several implications, assuming catch rate is related to abundance. Firstly, the preservation of shallow, often seasonally dry, habitats with plenty of cover is important for the preservation of black mudfish. Secondly, although mudfish occurred away from wetlands in habitats such as drains, they were usually more abundant in natural wetlands such as the Whangamarino Wetland complex. Drains appeared to be marginal habitats, usually with only low population densities at one-third of the sites sampled. The population at the one drain site with a high density (Site 32 ) is vulnerable to extinction through herbicides, pesticides, drainage, or cleaning. The preservation of large wetlands such as the Kopouatai Peat Dome and the Whangamarino Wetland complex is important for maintaining and protecting large populations of black mudfish, and their genetic diversity. Wetlands designated as reserves need to be large in area to maintain the integrity of their hydrology and value as black mudfish habitat. An example of an ineffective reserve is the 70-ha Moanatuatua Scientific Reserve, where no mudfish were found (Table 1, Appendix 1). It lacks buffers between it and the surrounding pasture, which is drained peatland. The water table has been lowered and adjacent peatland pasture has shrunk, and continues to shrink, at a rate of up to $6 \mathrm{~cm}$ per year (Humphreys 1990), owing to intensive agriculture. As a result, the reserve has become quite dry on top all year round, and has therefore lost all value as black mudfish habitat.

The continued presence of black mudfish in the Waikato region is likely, so long as enough viable habitats, such as the Whangamarino Wetland complex, remain. Their adaptability allows black mudfish to survive in some altered habitats, such as farm or roadside drains. However, marginal populations of black mudfish in drains around the Waikato region are under constant threat of disruption, because the primary function of drains can only be maintained with frequent removal of sediment and vegetation. Mosquitofish, which are widespread in the region and which may have up to three broods per year in the warmer months (Wakelin 1986), do not appear to exclude black mudfish from marginal habitats, but may contribute to the exclusion of mudfish from areas with yearround water. The continued existence of suitable habitats appears to be more important to black mudfish than the presence of predators and competitors. This study has improved methods of identifying suitable mudfish habitats in the Waikato region. An evaluation of the temporal component of factors that constrain black mudfish distribution, and extension of our findings to other regions, is now necessary.

\section{ACKNOWLEDGMENTS}

We thank Lee Laboyrie, Dudley Bell, and Barry O'Brien for technical assistance. Theo Stephens, John Green, Tracey Greenwood, Ian Boothroyd, Ann Chapman, Keith Thompson, and Adrian Meredith gave constructive criticism and assistance with study design. Tony Eldon, Ian Jowett, Russell Cole, and one anonymous referee also provided helpful comments. This investigation was carried out as part of RFGB's MSc thesis at the University of Waikato.

\section{REFERENCES}

Barrier, R. F. G. 1993: Investigation of habitat preferences of black mudfish in the Waikato region and their interaction with mosquitofish. Unpublished MSc thesis, University of Waikato, Hamilton, New Zealand. 86 p. 
Barrier, R. F. G.; Hicks, B. J. 1994: Behavioral interactions between black mudfish (Neochanna diversus Stokell, 1949: Galaxiidae) and mosquitofish (Gambusia affinis Baird and Girard, 1854). Ecology of freshwater fish 3: 93-99.

Bovee, K. D. 1986. Development and evaluation of habitat suitability criteria for use in the instream flow incremental methodology. United States Fish and Wildlife Service, Instream Flow and Aquatic Systems Group, Instream Flow Information Paper 21.235 p.

Dean, T. L. 1995: Environmental physiology of aquatic and aerial respiration in the black mudfish (Neochanna diversus Stokell, 1949). Unpublished MSc thesis, University of Waikato, Hamilton, New Zealand. $120 \mathrm{p}$

Department of Lands and Survey. 1978: New Zealand topographical map 1:50000 NZMS 260 sheet S12 Maramarua (1 st edition). Department of Lands and Survey, Wellington.

Department of Lands and Survey. 1979: New Zealand topographical map 1:50000 NZMS 260 sheet S14 Hamilton (1st edition). Department of Lands and Survey, Wellington.

Department of Lands and Survey. 1980: New Zealand topographical map 1:50000 NZMS 260 sheet S15 Te Awamutu (lst edition). Department of Lands and Survey, Wellington.

DSIR 1954: General survey of the soils of the North Island, New Zealand. New Zealand Soil Bureau Bulletin 5, sheet 3, Department of Scientific and Industrial Research, Wellington.

Eldon, G. A. 1978: The life history of Neochanna apoda Gunther (Pisces: Galaxiidae). Fisheries Research Division, New Zealand Ministry of Agriculture and Fisheries, Christchurch, New Zealand. Fisheries research bulletin $19.44 \mathrm{p}$.

Eldon, G. A. 1979a: Breeding, growth and aestivation of the Canterbury mudfish, Neochanna burrowsius (Salmoniformes: Galaxiidae). New Zealand journal of marine and freshwater research 13: 331-346.

Eldon, G. A. 1979b: Habitat and interspecific relationships of the Canterbury mudfish, Neochanna burrowsius (Salmoniformes: Galaxiidae). New Zealand journal of marine and freshwater research 13: 111-119.

Eldon, T, 1992. The difficulties of catching mudfish. Freshwater catch 48: 16-17.

Humphreys, E. A. 1990: Moanatuatua Scientific Reserve: conservation values of adjacent MAF peat block. Reserves-Scientific, Moanatuatua. Department of Conservation, Hamilton, New Zealand. Unpublished file RSF 005. 2 p.
Humphreys, E. A. 1991: Impacts on vegetation of the Whangamarino Wetland. In: Swamp restoration in the Whangamarino Wetland: statements in support of an application by the Department of Conservation and Auckland/Waikato Fish and Game Council to dam the Whangamarino River, thereby restoring valuable wetland habitat lost through lower water levels in the Waikato River. Department of Conservation, Hamilton, New Zealand, pp. 107-119.

Jowett, I. G.; Richardson, J. 1995: Habitat preferences of common, riverine New Zealand native fishes and implications for flow management. New Zealand journal of marine and freshwater research 29: 13-23.

McDowall, R. M. 1990: New Zealand freshwater fishes: a guide and natural history. Auckland, Heinemann educational books. 230 p.

McLea, M. C. 1986: Ohinewai regional resource study: biology and water quality. Waikato Valley Authority, Hamilton, New Zealand. Technical publication $37.199 \mathrm{p}$.

Nelson, J. S. 1984: Fishes of the world (2nd edition). New York, John Wiley and Sons. $523 \mathrm{p}$.

Ogle, C. C.; Cheyne, J. 1981: The wildlife and wildlife values of the Whangamarino Wetlands. New Zealand Wildlife Service, Department of Internal Affairs, Wellington, New Zealand. Fauna survey unit report $28.94 \mathrm{p}$.

Skrzynski, W. 1968: The Canterbury mudfish, Galaxias burrowsius Phillipps, a vanishing species. New Zealand journal of marine and freshwater research 2: 688-697.

Strickland, R. R. 1980: Fisheries aspects of the Whangamarino Swamp. Fisheries Research Division, New Zealand Ministry of Agriculture and Fisheries, Turangi, New Zealand. Fisheries environmental report $7.37 \mathrm{p}$.

Thompson, F. V. 1987: Notes on the black mudfish. Freshwater catch 32: 6-10.

Town, J. 1981: Black mudfish in the Whangamarino. Freshwater catch 12: 9.

Vant, W. N.; Davies-Colley, R. J. 1984: Factors affecting clarity of New Zealand lakes. New Zealand journal of marine and freshwater research 18 : 368-369.

Wakelin, R. 1986: The biology of Gambusia affinis in Lake Waahi, Huntly. MSc Thesis, University of Waikato, Hamilton, New Zealand. 93 p.

Wilkinson, L.; Hill, M.; Howe, P.; Birkenbeuel, G.; Beck, J.; Liu, J. 1994: SYSTAT for DOS: advanced applications, version 6 edition. SYSTAT Inc., Evanston, Illinois. 902 p.

Zar, J. H. 1984: Biostatistical analysis. Prentice Hall, Englewood Cliffs, New Jersey. 718 p. 
Appendix 1 Habitat data, catch rates of black mudfish, and associations of other fish species at 80 sites in the Waikato region between January and October 1992. SWD, summer water depth $(\mathrm{cm})$; WWD, winter water depth $(\mathrm{cm})$; MWD, maximum water depth $(\mathrm{cm})$; TDS, total dissolved solids $\left(\mathrm{g} \mathrm{m}{ }^{3}\right)$; SDO, surface dissolved oxygen $\left(\mathrm{g} \mathrm{m}^{-3}\right)$; SWV, surface water velocity $\left(\mathrm{m} \mathrm{s}^{-1}\right)$; TUR, turbidity (NTU); $\mathrm{CON}$, conductivity $\left(\mu \mathrm{S} \mathrm{cm}{ }^{1}\right) ; \mathrm{PH}$, $\mathrm{pH} ; \mathrm{HC}$, humic concentration $\left(\mathrm{A}_{440}\right.$ $\mathrm{m}^{-1}$ ); DSR, disturbance scale rating (see Table 3); SOILTYPE, soil type from maps; SUBTYPE, substrate type: $1=$ mineralised, $2=$ semi-mineralised, $3=$ peat: WATSOUR, water source: $1=$ river flood and rainfall, $2=$ rainfall only. For the following variables, $0=<20 \%$ water surface area occupied, $1=20 \%$ water surface area occupied; EMVEG, water surface occupied by emergent vegetation; SUBVEG, water surface occupied by submerged vegetation; SUBWOOD, water surface area occupied by submerged woody debris; TREEROOT, water surface area occupied by tree roots; OHVEG, water surface area covered by overhanging vegetation. For the following variables, $0=$ absence, and $1=$ presence; MUDFISH, GAMBUSIA, JUVEELS (juvenile eels), OTHER (common bullies and inanga). CPUE, catch per unit effort (fish per trap per night) of black mudfish; canonical score was calculated from unstandardised discriminant function (Table 7A)

\begin{tabular}{|c|c|c|c|c|c|c|c|c|c|c|c|c|c|c|c|c|c|c|c|c|c|c|c|c|c|}
\hline $\begin{array}{l}\text { Site } \\
\text { no. }\end{array}$ & SWD & WWD & MWD & TDS & SDO & WV & & CON & $\mathrm{PH}$ & $\mathrm{HC}$ & DSR & $\begin{array}{l}\text { SOIL } \\
\text { TYPE }\end{array}$ & $\begin{array}{l}\text { SUB- } \\
\text { TYPE }\end{array}$ & $\begin{array}{l}\text { WAT- } \\
\text { SOUR }\end{array}$ & $\begin{array}{l}\text { EM- } \\
\text { VEG }\end{array}$ & $\begin{array}{l}\text { SUB- } \\
\text { VEG }\end{array}$ & $\begin{array}{c}\text { SUB- } \\
\text { WOOD }\end{array}$ & $\begin{array}{l}\text { TREE- } \\
\text { ROOT }\end{array}$ & $\begin{array}{l}\mathrm{OH}- \\
\mathrm{VEG}\end{array}$ & $\begin{array}{l}\text { MUD } \\
\text { FISH }\end{array}$ & & $\begin{array}{l}\text { GAM- } \\
\text { BUSIA }\end{array}$ & JUV- & & $\begin{array}{l}\text { CANONICAI } \\
\text { R SCORE }\end{array}$ \\
\hline 1 & 35 & 39 & 48 & 37.5 & 2.5 & 0.02 & 24.0 & 46 & 4.3 & 21.4 & 5 & 1 & 3 & 1 & 1 & 0 & 0 & 0 & 1 & 0 & 0.0 & 0 & 0 & 0 & 2.515 \\
\hline 2 & 42 & 48 & 65 & 26.9 & 5.4 & 0.00 & 3.6 & 34 & 4.2 & 13.6 & 5 & 1 & 3 & 1 & 1 & 1 & 0 & 0 & 0 & 0 & 0.0 & 0 & 0 & 0 & 2.064 \\
\hline 3 & 58 & 69 & 150 & 31.5 & 7.0 & 0.00 & 19.0 & 38 & 4.4 & 16.8 & 5 & 1 & 3 & 1 & 1 & 1 & 0 & 0 & 1 & 0 & 0.0 & 0 & 0 & 0 & 2.817 \\
\hline 4 & 12 & 17 & 50 & 32.8 & 8.5 & 0.03 & 2.1 & 41 & 3.9 & 35.0 & 5 & 1 & 3 & 1 & 0 & 0 & 0 & 0 & 0 & 0 & 0.0 & 0 & 0 & 0 & 1.082 \\
\hline 5 & 22 & 31 & 40 & 32.6 & 6.0 & 0.00 & 1.5 & 40 & 3.9 & 11.3 & 5 & 1 & 3 & 1 & 0 & 1 & 1 & 0 & 1 & 0 & 0.0 & 0 & 0 & 0 & 1.217 \\
\hline 6 & 54 & 60 & 105 & 38.3 & 3.0 & 0.00 & 13.0 & 56 & 5.7 & 1.2 & 4 & 2 & 1 & 2 & 1 & 1 & 1 & 1 & 1 & 0 & 0. & 1 & 0 & 0 & 2.043 \\
\hline 7 & 49 & 53 & 84 & 62.3 & 10.0 & 0.08 & 10.0 & 93 & 5.9 & 2.1 & 4 & 2 & 1 & 1 & 1 & 1 & 1 & 1 & 1 & 0 & 0.0 & 1 & 0 & 0 & 1.880 \\
\hline 8 & 23 & 31 & 45 & 55.7 & 1.5 & 0.00 & 37.0 & 81 & 6.0 & 11.3 & 4 & 2 & 2 & 1 & 1 & 1 & 1 & 1 & 1 & 0 & 0.0 & 0 & 1 & 0 & 1.637 \\
\hline 9 & 20 & 20 & 42 & 40.1 & 8.6 & 0.09 & 4.3 & 61 & 6.2 & 1.2 & 5 & 2 & 1 & 1 & 0 & 0 & 0 & 0 & 0 & 0 & 0.0 & 0 & 1 & 0 & 1.626 \\
\hline 10 & 117 & 128 & 160 & 56.2 & 9.2 & 0.12 & 6.5 & 81 & 6.3 & 1.8 & 5 & 2 & 1 & 1 & 1 & 1 & 0 & 0 & 0 & 0 & 0.0 & 1 & 0 & 0 & 4.387 \\
\hline 11 & 36 & 56 & 120 & 64.5 & 1.1 & 0.00 & 14.0 & 84 & 5.9 & 26.3 & 5 & 4 & 1 & 2 & 1 & 1 & 1 & 1 & 0 & 0 & 0.0 & 1 & 1 & 0 & 1.558 \\
\hline 12 & 0 & 20 & 50 & 49.1 & 1.0 & 0.00 & 4.1 & 70 & 5.9 & 34.3 & 4 & 4 & 2 & 2 & 1 & 1 & 1 & 1 & 1 & 1 & 1.0 & 0 & 0 & 0 & -0.596 \\
\hline 13 & 11 & 30 & 70 & 47.7 & 1.5 & 0. & & 6 & & 32.7 & 4 & 4 & 2 & 2 & 1 & 1 & 1 & 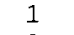 & 1 & 1 & 0.6 & 1 & 1 & 0 & -0.180 \\
\hline 14 & 0 & 16 & 35 & 22.8 & 3.6 & 0.00 & 6.2 & 38 & 5.1 & 12.4 & 1 & 4 & 3 & 2 & 1 & 1 & 0 & ( & 1 & 1 & 0.6 & 0 & 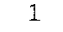 & 0 & -2.422 \\
\hline 15 & 78 & 84 & 115 & 20.5 & 2.6 & 0.16 & 4.0 & 30 & 5.2 & 9.4 & 3 & 4 & 3 & 2 & 1 & 0 & 1 & the & 0 & 0 & 0.0 & 0 & ( & 0 & 1.881 \\
\hline 16 & 0 & 14 & 30 & 135.0 & 1.6 & 0.00 & 23.0 & 192 & 6.5 & 12.0 & 4 & 5 & 2 & 2 & 1 & 1 & 1 & 1 & 1 & 0 & 0.0 & 0 & 0 & 0 & 0.215 \\
\hline 17 & 0 & 24 & 40 & 42.5 & 1.0 & 0.00 & 10.0 & 67 & 5.6 & 64.9 & 1 & 1 & 3 & 2 & 1 & 0 & 1 & 1 & 1 & 1 & 1.4 & 0 & 0 & 0 & -2.661 \\
\hline 18 & 0 & 14 & 35 & 18.3 & 3. & & 15. & 2 & 4. & 10.4 & 1 & 1 & 3 & 1 & 1 & 1 & 0 & 0 & 1 & 1 & 2 . & 0 & 0 & 0 & -2.079 \\
\hline 19 & 15 & 23 & 30 & 20.9 & 1.1 & 0.00 & & 29 & 4.6 & 8.3 & 1 & 1 & 3 & 1 & 1 & 1 & 0 & ( & 1 & 1 & 0 & 0 & 0 & 0 & -1. \\
\hline 20 & 46 & 51 & 500 & 26 . & 4.5 & 0.00 & 16.0 & 41 & 5.7 & 26.5 & 2 & 1 & 3 & 1 & 1 & 1 & 0 & 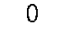 & 1 & 0 & 0.0 & 0 & 0 & 1 & 0.537 \\
\hline 21 & 23 & 83 & 150 & 74.6 & 5.2 & 0.01 & 7.5 & 105 & 4.5 & 7.8 & 5 & 1 & 1 & 2 & 1 & 0 & 0 & c & 1 & 1 & 0.4 & 1 & 0 & 0 & -0.805 \\
\hline 22 & 0 & 22 & 45 & 26.9 & 6.8 & 0.00 & 2.7 & 43 & 5.5 & 11.3 & 1 & 1 & 3 & 1 & 1 & 1 & 0 & ( & 1 & 1 & 2.8 & 0 & 0 & 0 & -2.786 \\
\hline 23 & 49 & 81 & 120 & 62.6 & 9.2 & 0.00 & 6.2 & 91 & 5.0 & 0.0 & 4 & 3 & 3 & 1 & 1 & 1 & 0 & c & 1 & 0 & 0.0 & 0 & 0 & 0 & 0.546 \\
\hline 24 & 14 & 30 & 45 & 81.1 & 4.0 & 0.00 & 7.8 & 107 & 5.4 & 9.2 & 2 & 1 & 3 & 1 & 1 & 1 & 0 & 0 & 1 & 1 & 8.4 & 1 & 0 & 0 & -1.230 \\
\hline 25 & 19 & 22 & 40 & 73.0 & 5.5 & 0.00 & 27.0 & 79 & 6.4 & 3.7 & 3 & 4 & 2 & 1 & 1 & 1 & 1 & 1 & 1 & 1 & 0.2 & 0 & 0 & 0 & 0.747 \\
\hline 26 & 8 & 46 & 120 & 70.1 & 7.0 & 0.00 & 91.0 & 76 & 6.4 & 40.5 & 5 & 3 & 1 & 2 & 0 & 1 & 1 & 1 & 0 & 0 & 0.0 & 0 & 0 & 1 & 2.089 \\
\hline 27 & 0 & 21 & 40 & 32.9 & 4.0 & 0.00 & 3.8 & 38 & 5.1 & 18.7 & 3 & 4 & 2 & 2 & 1 & 1 & 1 & 1 & 1 & 1 & 2 . & 0 & ( & 0 & -1.336 \\
\hline 28 & 0 & 31 & 50 & 37.6 & 7.0 & 0.02 & 2.5 & 41 & 5.1 & 18.9 & 4 & 4 & 2 & 2 & 1 & 1 & 0 & 1 & 1 & 1 & 0.4 & 0 & ( & 0 & -1.123 \\
\hline 29 & 0 & 47 & 60 & 29.2 & 5.7 & 0.01 & 3.3 & 33 & 5.2 & 23.5 & 3 & 4 & 2 & 2 & 1 & 1 & 1 & 1 & 1 & 1 & 0.2 & 0 & c & 0 & -2.487 \\
\hline 30 & 0 & 42 & 70 & 46.6 & 5.4 & 0.01 & 12.0 & 50 & 5.5 & 49.5 & 4 & 4 & 2 & 2 & 1 & 1 & 1 & 1 & 1 & 1 & 0. & 0 & 0 & 0 & -1.328 \\
\hline 31 & 0 & 68 & 70 & 51.0 & 7.9 & 0.03 & 43.0 & 75 & 6.4 & 5.8 & 5 & 1 & 3 & 1 & 0 & 0 & 0 & 0 & 0 & 0 & 0.0 & 0 & 0 & 0 & -0.878 \\
\hline 32 & 0 & 46 & 50 & 74.6 & 7.4 & 0.02 & 4.9 & 106 & 5.0 & 0.5 & 4 & 1 & 3 & 1 & 1 & 1 & 0 & 0 & 1 & 1 & 6.4 & 0 & 0 & 0 & -1.709 \\
\hline 33 & 0 & 42 & 45 & 111.0 & 5.5 & 0.01 & 69.0 & 160 & 6.1 & 7.8 & 5 & 1 & 3 & 1 & 0 & 0 & 0 & 0 & 1 & 0 & 0.0 & 0 & 0 & 0 & 1.014 \\
\hline 34 & 0 & 44 & 60 & 51.2 & 7.5 & 0.11 & 28.0 & 74 & 6.2 & 8.3 & 5 & 2 & 2 & 1 & 1 & 0 & 1 & 0 & 1 & 1 & 0.2 & 0 & 0 & 0 & -0.264 \\
\hline
\end{tabular}

(continued) 
Appendix 1 (continued)

\begin{tabular}{|c|c|c|c|c|c|c|c|c|c|c|c|c|c|c|c|c|c|c|c|c|c|c|c|c|c|}
\hline $\begin{array}{l}\text { Site } \\
\text { no. }\end{array}$ & SWD & $W W D$ & MWD & TDS & SDO & SWV & TUR & $\mathrm{CON}$ & $\mathrm{PH}$ & $\mathrm{HC}$ & DSR & $\begin{array}{l}\text { SOIL } \\
\text { TYPE }\end{array}$ & $\begin{array}{l}\text { SUB- } \\
\text { TYPE }\end{array}$ & $\begin{array}{l}\text { WAT- } \\
\text { SOUR }\end{array}$ & $\begin{array}{l}\text { EM- } \\
\text { VEG }\end{array}$ & $\begin{array}{l}\text { SUB- } \\
\text { VEG }\end{array}$ & $\begin{array}{l}\text { SUB- } \\
\text { WOOD }\end{array}$ & $\begin{array}{l}\text { TREE- } \\
\text { ROOT }\end{array}$ & $\begin{array}{l}\mathrm{OH}- \\
\text { VEG }\end{array}$ & $\begin{array}{l}\text { MUD } \\
\text { FISH }\end{array}$ & CPUE & $\begin{array}{l}\text { GAM- } \\
\text { BUSIA }\end{array}$ & $\begin{array}{l}\text { JUV. } \\
\text { EELS }\end{array}$ & $\begin{array}{r}\mathrm{C} \\
\text { OTHER }\end{array}$ & $\begin{array}{l}\text { ANONICAL } \\
\text { SCORE }\end{array}$ \\
\hline 35 & 0 & 48 & 65 & 87.7 & 7.1 & 0.07 & 20.0 & 127 & 5.4 & 7.6 & 5 & 2 & 2 & 1 & 1 & 1 & 1 & 0 & 1 & 1 & 0.2 & 0 & 0 & 0 & -0.671 \\
\hline 36 & 0 & 26 & 35 & 48.9 & 6.5 & 0.00 & 6.8 & 66 & 6.3 & 6.2 & 4 & 1 & 2 & 1 & 1 & 1 & 1 & 1 & 1 & 1 & 0.6 & 0 & 1 & 0 & -0.780 \\
\hline 37 & 0 & 24 & 30 & 45.0 & 6.3 & 0.00 & 4.5 & 67 & 6.2 & 7.4 & 2 & 1 & 3 & 1 & 1 & 1 & 1 & 1 & 1 & 1 & 1.2 & 0 & 0 & 0 & -2.134 \\
\hline 38 & 0 & 23 & 40 & 93.6 & 10.0 & 0.01 & 8.0 & 115 & 6.5 & 3.7 & 4 & 1 & 2 & 1 & 1 & 1 & 1 & 1 & 1 & 1 & 0.4 & 0 & 0 & 0 & -0.614 \\
\hline 39 & 0 & 18 & 30 & 47.7 & 5.3 & 0.00 & 5.4 & 72 & 6.1 & 4.8 & 2 & 1 & 3 & 1 & 1 & 1 & 0 & 0 & 1 & 1 & 1.0 & 0 & 0 & 0 & -1.845 \\
\hline 40 & 8 & 59 & 65 & 57.3 & 7.0 & 0.00 & 16.0 & 80 & 6.4 & 5.3 & 5 & 3 & 1 & 1 & 1 & 1 & 0 & 0 & 0 & 0 & 0.0 & 0 & 0 & 0 & -0.656 \\
\hline 41 & 6 & 25 & 40 & 65.3 & 1.4 & 0.00 & 5.5 & 120 & 6.6 & 6.9 & 4 & 2 & 2 & 1 & 0 & 1 & 0 & 0 & 1 & 0 & 0.0 & 1 & 0 & 0 & -0.315 \\
\hline 42 & 0 & 22 & 60 & 52.1 & 1.3 & 0.06 & 15.0 & 93 & 6.0 & 4.6 & 4 & 3 & 2 & 1 & 0 & 1 & 1 & 1 & 1 & 0 & 0.0 & 0 & 1 & 1 & -0.367 \\
\hline 43 & 9 & 15 & 25 & 71.0 & 6.0 & 0.02 & 30.0 & 138 & 6.4 & 4.4 & 4 & 5 & 1 & 1 & 1 & 0 & 1 & 0 & 1 & 0 & 0.0 & 0 & 0 & 0 & 1.063 \\
\hline 44 & 34 & 80 & 95 & 56.9 & 1.2 & 0.00 & 9.5 & 111 & 6.6 & 1.6 & 5 & 3 & 2 & 1 & 1 & 1 & 0 & 0 & 0 & 0 & 0.0 & 1 & 0 & 1 & 0.225 \\
\hline 45 & 0 & 35 & 50 & 59.5 & 1.5 & 0.00 & 7.5 & 115 & 6.5 & 8.3 & 4 & 1 & 2 & 1 & 1 & 0 & 1 & 1 & 1 & 1 & 0.4 & 0 & 0 & 0 & -1.153 \\
\hline 46 & 0 & 22 & 30 & 72.0 & 4.8 & 0.00 & 18.0 & 134 & 6.6 & 39.2 & 3 & 2 & 2 & 2 & 1 & 0 & 1 & 1 & 1 & 1 & 0.2 & 0 & 0 & 0 & -0.967 \\
\hline 47 & 12 & 29 & 50 & 62.7 & 0.8 & 0.00 & 14.0 & 110 & 7.3 & 25.3 & 5 & 5 & 1 & 1 & 0 & 1 & 0 & 0 & 0 & 0 & 0.0 & 1 & 0 & 1 & 0.903 \\
\hline 48 & 0 & 35 & 40 & 43.5 & 1.0 & 0.00 & 30.0 & 73 & 6.2 & 15.4 & 4 & 5 & 2 & 1 & 1 & 0 & 0 & 0 & 0 & 1 & 0.4 & 1 & 0 & 0 & -0.500 \\
\hline 49 & 11 & 18 & 25 & 47.6 & 1.3 & 0.05 & 14.0 & 85 & 6.6 & 2.8 & 4 & 5 & 1 & 2 & 0 & 1 & 1 & 1 & 1 & 0 & 0.0 & 1 & 0 & 0 & 0.620 \\
\hline 50 & 0 & 25 & 32 & 41.6 & 2.2 & 0.04 & 11.0 & 73 & 4.3 & 47.4 & 4 & 1 & 3 & 1 & 1 & 1 & 0 & 0 & 1 & 1 & 0.4 & 0 & 0 & 0 & -0.614 \\
\hline 51 & 41 & 63 & 150 & 54.3 & 4.3 & 0.00 & 14.0 & 93 & 6.5 & 15.9 & 4 & 1 & 3 & 1 & 0 & 1 & 0 & c & 0 & 0 & 0.0 & 0 & 0 & 0 & 0.947 \\
\hline 52 & 19 & 35 & 200 & 49.1 & 8.8 & 0.08 & 6.6 & 88 & 6.1 & 17.3 & 5 & 1 & 3 & 1 & 0 & 1 & 0 & 0 & 0 & 0 & 0.0 & 0 & 0 & 0 & 0.961 \\
\hline 53 & 22 & 39 & 55 & 46.8 & 9.2 & 0.00 & 5.7 & 83 & 6.7 & 19.3 & 4 & 1 & 3 & 1 & 0 & 1 & 1 & 0 & 1 & 0 & 0 & 0 & 0 & 0 & 0.302 \\
\hline 54 & 0 & 22 & 32 & 125.1 & 0.8 & 0.00 & 15.0 & 223 & 5.3 & 32.7 & 4 & 1 & 3 & 1 & 1 & 1 & 0 & 0 & 1 & 0 & 0.0 & 0 & 0 & 0 & -0.367 \\
\hline 55 & 8 & 26 & 45 & 45.8 & 0.8 & 0.00 & 12.0 & 84 & 5.5 & 32.2 & 3 & 1 & 2 & 1 & 1 & 1 & 1 & 1 & 1 & 0 & 0.0 & 0 & 0 & 0 & -0.705 \\
\hline 56 & 0 & 18 & 35 & 61.3 & 4.2 & 0.00 & 24.0 & 103 & 6.4 & 23.7 & 3 & 2 & 2 & 1 & 1 & 1 & 1 & 1 & 1 & 1 & 0.6 & 0 & 0 & 0 & -0.618 \\
\hline 57 & 0 & 17 & 30 & 62.4 & 1.2 & 0.00 & 3.9 & 102 & 6.3 & 4.1 & 3 & 2 & 2 & 1 & 1 & 1 & 1 & 1 & 1 & 1 & 0.2 & 0 & 0 & 0 & -1.158 \\
\hline 58 & 0 & 23 & 30 & 64.8 & 5.1 & 0.04 & 8.2 & 105 & 6.7 & 6.0 & 3 & 2 & 2 & 2 & 1 & 1 & 1 & 1 & 1 & 1 & 1.8 & 1 & 0 & 0 & -1.295 \\
\hline 59 & 0 & 20 & 72 & 89.2 & 0.8 & 0.00 & 19.0 & 138 & 6.3 & 5.3 & 4 & 2 & 2 & 1 & 1 & 0 & 1 & 1 & 1 & 1 & 0.4 & 0 & 1 & 0 & -0.164 \\
\hline 60 & 0 & 16 & 40 & 86.3 & 3.2 & 0.09 & 3.3 & 135 & 6.6 & 6.9 & 3 & 2 & 2 & 1 & 1 & 1 & 1 & 1 & 1 & 1 & 1.8 & 1 & 0 & 0 & -1.132 \\
\hline 61 & 31 & 43 & 130 & 47.0 & 8.5 & 0.16 & 1.8 & 77 & 6.5 & 0.2 & 5 & 2 & 1 & 1 & 1 & 1 & 0 & 0 & 0 & 0 & 0.0 & 0 & 0 & 0 & 1.390 \\
\hline 62 & 0 & 19 & 25 & 73.9 & 3.5 & 0.00 & 22.0 & 124 & 5.0 & 38.9 & 5 & 1 & 3 & 1 & 1 & 1 & 0 & 0 & 1 & 0 & 0.0 & 0 & 0 & 0 & 0.654 \\
\hline 63 & 7 & 24 & 30 & 67.3 & 2.1 & 0.00 & 15.0 & 105 & 6.7 & 14.3 & 4 & 1 & 2 & 1 & 1 & 1 & 1 & 1 & 1 & 0 & 0.0 & 1 & 0 & 0 & 0.081 \\
\hline 64 & 0 & 29 & 33 & 43.2 & 2.5 & 0.05 & 14.0 & 79 & 4.4 & 43.5 & 4 & 1 & 3 & 1 & 1 & 1 & 0 & 0 & 0 & 1 & 0.4 & 0 & 0 & 0 & -0.702 \\
\hline 65 & 0 & 22 & 30 & 48.4 & 0.9 & 0.02 & 9.0 & 81 & 4.7 & 28.3 & 4 & 1 & 3 & 1 & 1 & 1 & 1 & 0 & 1 & 1 & 0.4 & 0 & 1 & 0 & -0.541 \\
\hline 66 & 0 & 30 & 45 & 52.0 & 5.4 & 0.14 & 6.0 & 81 & 5.1 & 28.8 & 4 & 3 & 2 & 1 & 1 & 1 & 1 & 1 & 1 & 1 & 0.2 & 0 & 1 & 0 & -0.978 \\
\hline 67 & 16 & 24 & 387 & 100.6 & 5.6 & 0.00 & 15.0 & 156 & 6.7 & 6.9 & 5 & 2 & 1 & 1 & 1 & 1 & 0 & 0 & 1 & 0 & 0.0 & 0 & 0 & 0 & 1.456 \\
\hline 68 & 0 & 17 & 23 & 54.2 & 0.6 & 0.00 & 7.0 & 83 & 6.4 & 30.4 & 2 & 2 & 2 & 1 & 1 & 1 & 1 & 1 & 1 & 0 & 0.0 & 0 & 0 & 0 & -1.755 \\
\hline 69 & 0 & 45 & 58 & 48.9 & 1.3 & 0.07 & 16.0 & 68 & 6.3 & 7.1 & 4 & 1 & 2 & 1 & 1 & 1 & 1 & 0 & 1 & 1 & 0.6 & 0 & 0 & 0 & -1.343 \\
\hline 70 & 0 & 43 & 50 & 53.1 & 1.5 & 0.12 & 21.0 & 78 & 6.2 & 9.7 & 4 & 1 & 3 & 1 & 1 & 1 & 0 & 0 & 1 & 1 & 0.2 & 0 & 0 & 0 & -1.111 \\
\hline 71 & 0 & 31 & 60 & 91.2 & 0.8 & 0.00 & 38.0 & 142 & 4.7 & 25.1 & 5 & 1 & 3 & 1 & 1 & 1 & 0 & 0 & 1 & 0 & 0.0 & 0 & 0 & 0 & 0.594 \\
\hline 72 & 4 & 20 & 351 & 176.7 & 1.9 & 0.04 & 35.0 & 278 & 6.0 & 27.9 & 5 & 1 & 2 & 1 & 1 & 0 & 0 & 0 & 1 & 0 & 0.0 & 0 & 1 & 0 & 1.294 \\
\hline 73 & 25 & 40 & 55 & 90.6 & 3.4 & 0.09 & 14.0 & 138 & 6.2 & 3.2 & 4 & 2 & 1 & 1 & 1 & 0 & 1 & 1 & 1 & 0 & 0.0 & 0 & 0 & 0 & 0.729 \\
\hline 74 & 0 & 16 & 201 & 148.3 & 0.7 & 0.00 & 81.0 & 236 & 6.6 & 10.6 & 4 & 2 & 2 & 1 & 1 & 1 & 1 & 1 & 1 & 0 & 0.0 & 0 & 0 & 0 & 1.811 \\
\hline 75 & 13 & 24 & 301 & 117.6 & 2.8 & 0.05 & 86.0 & 187 & 5.4 & 0.5 & 5 & 1 & 3 & 1 & 0 & 0 & 1 & 0 & 1 & 0 & 0.0 & 0 & 0 & 0 & 3.288 \\
\hline 76 & 12 & 21 & 25 & 73.4 & 6.9 & 0.17 & 15.0 & 110 & 6.7 & 7.8 & 5 & 1 & 3 & 1 & 0 & 0 & 1 & 0 & 0 & 0 & 0.0 & 0 & 1 & 1 & 1.281 \\
\hline 77 & 0 & 21 & 241 & 125.3 & 4.4 & 0.04 & 16.0 & 187 & 5.4 & 6.2 & 4 & 1 & 3 & 1 & 1 & 1 & 0 & 0 & 1 & 1 & 1.8 & 0 & 1 & 0 & -0.294 \\
\hline 78 & 0 & 26 & 381 & 123.4 & 3.5 & 0.03 & 13.0 & 185 & 6.5 & 3.2 & 4 & 2 & 2 & 2 & 1 & 1 & 1 & 1 & 1 & 1 & 0.8 & 1. & 0 & 0 & -0.600 \\
\hline 79 & 0 & 32 & 45 & 94.2 & 1.1 & 0.00 & 21.0 & 146 & 6.6 & 9.4 & 4 & 2 & 2 & 1 & 1 & 0 & 1 & 1 & 1 & 1 & 0.6 & 0 & 0 & 0 & -0.630 \\
\hline 80 & 0 & 14 & 20 & 90.8 & 1.4 & 0.00 & 16.0 & 132 & 6.4 & 8.5 & $\leq$ & 2 & 2 & 1 & 1 & 1 & 1 & 1 & 1 & 1 & 1.4 & 0 & 1 & 0 & 0.012 \\
\hline
\end{tabular}

